\title{
The use of ICT tools to support collaborative product development activities: evidences from Brazilian industry
}

\author{
Daisy Valle Enriquea, Néstor Fabián Ayalaa, Mateus José do Rêgo Ferreira Limaa, \\ Giuliano Almeida Marodin ${ }^{\mathrm{b}}$, Lilia Gzarac ${ }^{\mathrm{c}}$, Alejandro Germán Frank ${ }^{\mathrm{a} *}$ \\ aDepartamento de Engenharia de Produção, Universidade Federal do Rio Grande do Sul, Porto Alegre, RS, Brasil \\ ${ }^{\text {b}}$ Darla Moore School of Business, University of South Carolina, Columbia, SC, United States \\ 'Institut Polytechnique de Grenoble, Grenoble, Rhône-Alpes, France \\ *frank@producao.ufrgs.br
}

\begin{abstract}
Paper aims: This paper aims to understand the relationship between Information \& Communication Technology (ICT), collaborative New Product Development (NPD) and customer satisfaction (NPD performance).
\end{abstract}

Originality: We target the relationship between ICT, collaborative NPD and NPD performance. ICT is assessed as a set of specific tools adopted by the companies.

Research method: We test the mediating role of collaborative practices in the effect of ICT tools on customer satisfaction (as NPD performance) by means of a survey of 105 Brazilian firms.

Main findings: Collaboration with customers and suppliers has an important role for customer satisfaction and the use of ICT has significant effect on NPD performance through the mediating role of collaborative practices.

Implications for theory and practice: Implementing only ICT tools is not enough to achieve higher level of success in NPD. Managers should first strength the relationship between stakeholders and then adopt ICT tools to support the cooperation. Keywords

Collaborative practices. Information and communication technologies. New product development.

How to cite this article: Enrique, D. V., Ayala, N. F., Lima, M. J. R. F., Marodin, G. A., Gzara, L., \& Frank, A. G. (2018). The use of ICT tools to support collaborative product development activities: evidences from Brazilian industry. Production, 28, e20170099. http://dx.doi.org/10.1590/0103-6513.20170099.

Received: Dec. 20, 2017; Accepted: Apr. 26, 2018

\section{Introduction}

Collaboration with stakeholders is an important aspect of new product development (NPD) management. Literature defends that a higher degree of collaboration may promote several benefits, for instance: cost reduction (Sjoerdsma \& Van Weele, 2015), reduction of time to market (Ragatz et al., 2002), knowledge transferring and skills improvement among partners (Frank et al., 2015; Frank \& Echeveste, 2012) and improvement on product quality (Primo \& Amundson, 2002).

Such collaboration has gained a notable relevance due to changes that happened in recent years in terms of firm's innovation patterns. Also, there has been a considerable shift in Research \& Development (R\&D) practices, which evolved from closed to open innovation approaches (Chesbrough, 2006), not only in developed countries, but also in emerging economies, such as the Brazilian one (Frank et al., 2016). Consequently, firms have been more concerned with the development of collaboration in the R\&D field, focusing on strategies such as "open innovation" and "codesign" (Storbacka et al., 2012). To sustain the market demands, firms are now being required to develop stronger links and higher levels of communication with their stakeholders in order 
to share knowledge and manage information about NPD projects, as well as to make joint decisions regarding design specifications, product manufacturability, and process design (Park \& Lee, 2014; Wang et al., 2008).

In this context, Information and Communication Technology (ICT) tools play an essential role by facilitating this external-oriented organizational learning process based on knowledge alliances and knowledge networks between firms (Dong \& Yang, 2015). However, the current research on ICT has been more interested in investigating a limited number of ICT issues, such as the diffusion and implementation of these tools (e.g. Roztocki \& Weistroffer, 2015), whose main focus has been frequently associated to the company's internal use of ICT tools. This literature considers frequently ICT adoption as a single artifact, while few studies address the adoption of specific types of technologies (Kim et al., 2011). Few works have investigated the adoption of ICT tools for external or inter-firm collaboration and at a specific tools level of analysis (Marra et al., 2012; Marion et al., 2014; Dong \& Yang, 2015). Thus, there is a theoretical gap in the literature regarding the impact of specific sets of ICT tools on both external collaboration and NPD performance as well as the way in which these three aspects (ICT tools, collaborative NPD and NPD performance) are associated. This gap may be the reason why the adoption of ICT and its use, essentially for NDP process, seems to be still limited in a firm's context, especially in the context of SMEs (Barczak et al., 2008; Peng et al., 2014; Reid et al., 2016). Moreover, studies about the use of ICT tools for cooperation and innovation have been mostly developed in firms located in developed countries. Nevertheless, as shown by Frank et al. (2016) and Gu \& Lundvall (2006), product innovation in developing countries face different types challenges. Innovation in emerging countries, such as China, India and Brazil, is still maturing and may represent a greater challenge for companies (Frank et al., 2016). At the same time, innovation is also considered one of the most essential paths for a firm to achieve an international level of competitiveness, once this strategy may promote improvements in productivity and economic growth (Ngwenyama \& Morawczynski, 2009; McGrath \& Maiye, 2010; Watkins et al., 2015). In this sense, one way to improve innovation activities in emerging countries is through the establishment of strategic alliances with other successful firms (Tavallaei et al., 2015), supported by the use of ICT tools (Ngwenyama \& Morawczynski, 2009). Emerging countries, such as Brazil, are experiencing a solid development regarding the adoption of ICT tools in several industrial sectors (Cortimiglia et al., 2012). However, there is still a lack of studies about how these tools can improve collaboration on NPD.

Hence, considering this scenario and aiming to shed light on the abovementioned unexplored aspects, this paper intends to answer the following research question: What is the contribution of ICT tools for both collaborative NPD activities and NPD performance in the Brazilian context? Specifically, this paper investigates: (i) the impact of specific ICT tools adoption on collaborative practices in the context of a developing country, as well as (ii) the role of "collaborative practices" as a mediator of the relationship between ICT and NPD performance.

\section{Theoretical background: 1CT adoption theory}

ICT adoption and their use has been considered in the literature from many different theoretical perspectives (e.g. Ajzen, 1991; Delone \& Mclean, 1992; Venkatesh et al., 2012). Most of the works on this topic are concerned with the understanding of why and how people and organizations adopt and use ICT tools (Kim et al., 2011). This analysis comprehends three main stages of the adoption process, according to Kim et al. (2011): (i) Pre-adoption - where technologies are examined and considered for the adoption; (ii) Adoption - where there is an intention to adopt, purchase and use these technologies; and Post-Adoption - in which the persistence of use or abandon of the ICT is analyzed. Recently, other works have extended this knowledge on ICT adoption to its implications for organizational performance (e.g. Lapierre \& Denier, 2005; Bryan et al., 2014; Tarute \& Gatautis, 2014). These works consider the level of adoption as an antecedent of different perceived benefits that the organization may achieve. In this sense, there are works that relate the ICT adoption theory to the performance of intra and inter-organizational collaborative activities (Ahuja et al., 2009; Kim et al., 2011; Bryan et al., 2014) and its association to innovation and product development (Ulmanis \& Deniņš, 2012; Tarutė \& Gatautis, 2014), which are the focus of our research.

Additionally, the extant research on ICT adoption considers ICT frequently as a single artifact, while few studies address the adoption of a set of technologies (Kim et al., 2011). In other words, most of the studies consider whether the ICT concept has been adopted in companies independently of which specific tools that can be used. Nonetheless, the analysis about the contribution of specific ICT tools can shed light on important aspects of the collaborative NPD environment (e.g. Montoya et al., 2009; Peng et al., 2014). 
Here, we considered specifically the adoption stage, which comprehends the acquisition and early usage phases. Also, considered the level of adoption in the company's unit. Secondly, instead of studying "why" or "how" ICT tools are adopted, we followed the second stream, which considers the impact produced by this adoption. Third, we did not consider ICT adoption constructs already discussed in the literature. We followed the research stream that considers different specific tools of ICT from the NPD context that can be considered in the adoption decision and after we grouped them into a single construct called ICT tools. Finally, focused on a developing country context, where the level of adoption of ICT tools may differ when compared to a developed economy (Ulmanis \& Deninšs, 2012; Gono et al., 2016).

\section{Hipotheses development}

\subsection{Impact of ICT tools adoption on product performance and on NPD collaborative practices}

The product innovation literature has provided empirical evidence regarding the positive impact of ICT tools on product performance. For instance, Vilaseca-Requena et al. (2007) found that ICT use contributes for the efficiency and for the reduction of barriers to innovate. Moreover, Barczak et al. (2007) demonstrated that ICT adoption contributes for the improvement of two NPD performance dimensions: (i) speed to market and (ii) market performance. Finally, Chen (2007) also showed that IT capabilities influence corporate entrepreneurship and product innovation performance. In addition, more recent research approaches the implications of Industry 4.0, where there is an intensive use of digital technologies. They affirm that one important feature of this strategy to support the integration and virtualization of the production and design processes so that smarter products can be created (Santos et al., 2017; Nunes et al., 2017). This digitalization, which is the basis of Industry 4.0, allows the monitoring and control of the products developed, thus enabling the collection of data from the operation of these products for subsequent optimization of the development processes and the redesign of the products (lsaksson et al., 2017).

However, there are two potential theoretical gaps in the literature that must be highlighted. Firstly, as demonstrated by Montoya et al. (2009), different patterns of ICT tools adoption have different levels of perceived performance. Therefore, the impact that ICT adoption promote on NPD performance may depend on the types of ICT tools used and, in this sense, most of the authors consider ICT adoption as a general concept without discriminating which specific tools should be used. Here, although we study eleven types of ICT in a single construct, we investigated in our survey the adoption of ICT tools individually. Moreover, even when Barczak et al. (2007) showed positive effects of the ICT adoption on NPD performance, in another study, the same authors showed that these impacts may differ among country's (Barczak et al., 2008), evincing that regional characteristics should be taken into account. Therefore, since most studies are associated with the developed countries context, we seek to conduct an empirical analysis using data from a developing country. Hence, we suggest the following hypothesis:

H1: The extent in which ICT tools are adopted exert a positive impact on the NPD performance (customer satisfaction).

The NPD literature emphasizes that ICT tools promote not only a contribution for the NPD performance itself, but also for the integration among teams (Ettlie \& Pavlou, 2006; Song \& Song, 2010; Peng et al., 2014; Li et al., 2017). In order to reduce the impact of such a distance between partners and to enable communication and collaboration across boundaries, many authors suggest the adoption of ICT tools to manage virtual NPD teams (e.g. Griffith \& Sawyer, 2006; Montoya et al., 2009). In this context, the role of ICT tools is mostly intended to facilitate the external-oriented organizational learning process (Bombaywala \& Riandita, 2015). ICT tools have a large number of uses in the NPD process, most of them linked to communication, knowledge and information sharing (e.g. e-mail, videoconference and Electronic Data Interchange - EDI), which are useful to connect internal and external teams. Other tools, in turn, are more focused on codesign, complex real-time workflow management and coordination of NPD activities, enabling product design teams to collaborate across functional and organizational boundaries to gather and share design requirements, conduct design iterations and verify and test designs (Pavlou \& El Sawy, 2010; Marion et al., 2014; Peng et al., 2014). Others tools, such as Customer Relationship Management (CRM) and Supplier Relationship Management (SRM) may contribute to the involvement of customers and suppliers (Nazari-Shirkouhi, 2015). Moreover, ICT tools such as Business Intelligence (BI) (Wang, 2015), Demand Forecasting System (DFS) (Asimakopoulos \& Dix, 2013; Lehrer \& Behnam, 2009) and Online Sales Systems (Miyatake et al., 2016; Tontini, 2016) are some of the most used tools for NPD data collection and analysis. Therefore, considering the suggested contribution of this set of ICT tools for the companies, we propose a second hypothesis:

H2: The extent in which ICT tools are adopted exert a positive impact on NPD collaborative practices. 


\subsection{The impact of collaborative practices on NPD performance}

The NPD process involves complex and interrelated multidisciplinary activities. Therefore, internal cross-functional collaboration and mostly external collaboration with partners are essential features for the success of this process (Park \& Lee, 2014; Mu et al., 2017). For instance, firms that focus their NPD process on external collaboration can benefit from improved knowledge sharing with suppliers and greater positive results of the NPD project such as, reduction of product design flaws, improvement in NPD time-to-market and product quality which, in turn, influences the level of customer satisfaction (Langner \& Seidel, 2009; Park \& Lee, 2014; Sjoerdsma \& Van Weele, 2015; Chang, 2017). External partnership includes several distinct actors, such as customers, suppliers, universities and research institutes, and even competitors (Laage-Hellman et al., 2014). Among these partners, prior studies have highlighted that suppliers and customers are the most common ones (e.g. Tether, 2002; Backer et al., 2008; Peng et al., 2014; Mu et al., 2017).

The activities with suppliers in the NPD can range from informal consultancy to product design, involving each stage of the NPD process (Ragatz et al., 1997; Petersen et al., 2005). Lakemond et al. (2006) showed that the relationship with suppliers can vary depending on the phase of the NPD project: from a simple interaction between purchasers from both sides (company-supplier) to an integrated project where both teams are engaged in the development of a solution. By pursuing a more effective collaboration with suppliers, NPD teams can use several NPD practices. Some of these practices are focused on the development of an effective communication to enhance trust among partners, which is considered essential for collaboration and information sharing improvement, so that they can understand the partners' needs and requirements (Ragatz et al., 1997; Büyüközkan \& Arsenyan, 2012). In addition, by establishing mutual understanding and goals, the company is able to explore external knowledge and to create innovative products (Wong et al., 2013).

Moreover, literature has shown that suppliers' involvement is positively associated with improvements in product design and design for manufacturability considerations (Wasti \& Liker, 1997; Primo \& Amundson, 2002; Ragatz et al., 1997). Successful suppliers' involvement requires a learning routine and a set of capabilities to ensure that both parties are aligned for joint projects (Wong et al., 2013). Thus, it is possible to conclude that the success of involving suppliers in the NPD depends on the firm's ability to achieve long-term collaboration and that companies must focus on strategic management activities and long-term relationships with key suppliers (Van Echtelt et al., 2006).

Additionally, customers involvement also plays also a crucial role in collaborative NPD because it allows companies to obtain knowledge about market expectations and to develop new products aligned with them (Laage-Hellman et al., 2014; La Rocca et al., 2016). The use of customer knowledge may increase the competitive advantage of the products and become a source of innovation and idea generation. Since this kind of interaction focuses on the customer as the end-user, some activities should target information and knowledge exchange to promote a joint problem-solving to foster the innovation process (Laage-Hellman et al., 2014). In this sense, gathering and analyzing customer-related information, conducting marketing studies and identifying and cooperating with lead users are all examples of activities that may enhance levels of customer satisfaction. Therefore, the context analyzed leads us to propose the following hypothesis:

H3: Higher levels of collaboration with suppliers and customers for NPD activities is associated with higher levels of NPD performance (customer satisfaction).

\subsection{Research model consolidation}

The three hypotheses proposed in this work are illustrated in Figure 1. As shown, we considered the level of costumer satisfaction as our NPD performance metric (Consoli, 2012). Thus, our model proposes that customer satisfaction may be improved through the establishment of collaborative practices with suppliers and customers. Also, we propose that ICT tools provide support for these collaborative practices, and that these ICT tools may have a direct impact on the NPD performance even when collaborative practices are not primarily established. This last assumption is justified by the fact that ICT tools can simply approximate customers to the company, which may contribute to the NPD process and, consequently, to the level of customer satisfaction (Hemetsberger \& Godula, 2007). 


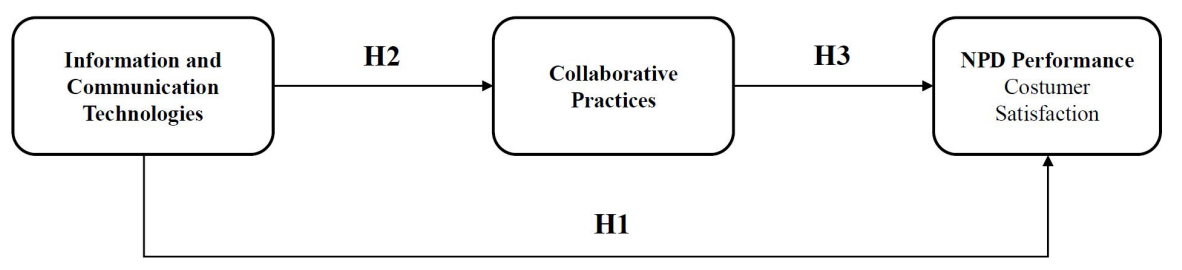

Figure 1. Theoretical model.

\section{Research methods}

\subsection{Sampling and measures}

To investigate the proposed hypotheses, we performed a cross-sectional survey in Brazilian manufacturing companies. We distributed a survey to the 470 industrial attendees of the 2014 IV Conference of Lean Systems in Porto Alegre, Brazil. The survey was distributed through on-site questionnaires and e-mail with sub-sequent follow-ups. From the 470 attendees we obtained 105 useable questionnaires for the variables considered in this paper, a response rate of $22.34 \%$. Table 1 shows the sample composition.

Table 1. Sample composition.

\begin{tabular}{|c|c|c|c|c|c|c|c|}
\hline Category & Description & $\mathrm{N}^{\circ}$ & $(\%)$ & Category & Description & $\mathrm{N}^{\circ}$ & $(\%)$ \\
\hline \multirow{11}{*}{ Industrial sector } & Automotive & 25 & $23 \%$ & \multirow{6}{*}{$\begin{array}{l}\text { Company's } \\
\text { size }\end{array}$} & Small & \multirow{2}{*}{44} & \multirow{2}{*}{$42 \%$} \\
\hline & Metallurgical & 16 & $15 \%$ & & (<100 employees) & & \\
\hline & Food \& Beverage & 10 & $9 \%$ & & \multirow{2}{*}{$\begin{array}{c}\text { Medium } \\
\text { (100-500 employees) }\end{array}$} & \multirow{2}{*}{41} & \multirow{2}{*}{$39 \%$} \\
\hline & Furniture & 8 & $7 \%$ & & & & \\
\hline & Agroindustry & 8 & $7 \%$ & & \multirow{2}{*}{$\begin{array}{c}\text { Large } \\
\text { (>500 employees) }\end{array}$} & \multirow{2}{*}{20} & \multirow{2}{*}{$19 \%$} \\
\hline & Electronic & 7 & $6 \%$ & & & & \\
\hline & Petrochemical & 5 & $5 \%$ & \multirow{5}{*}{ Product complexity } & \multirow{2}{*}{ Low Complexity } & \multirow{2}{*}{37} & \multirow{2}{*}{$35 \%$} \\
\hline & Military weapons & 4 & $4 \%$ & & & & \\
\hline & Industrial equipment & 2 & $2 \%$ & & \multirow{2}{*}{ Medium complexity } & \multirow{2}{*}{23} & \multirow{2}{*}{$22 \%$} \\
\hline & Transportation & 2 & $2 \%$ & & & & \\
\hline & Others & 18 & $17 \%$ & & High complexity & 45 & $43 \%$ \\
\hline
\end{tabular}

The two explanatory variables were represented by constructs and composed by multiple-item scales created in accordance to different suggestions and empirical investigations from the literature. Firstly, the construct Information and Communication Technology tools [1CT_TOOLS] comprises eleven ICT tools commonly associated with product development (Table 2): electronic data interchange (EDI); vendor managed inventory (VMI); customer relationship management (CRM); business intelligence (BI); e-procurement, internet/intranet; supplier relationship management (SRM); computer integrated manufacturing (CIM); forecast demand systems; online sales systems and computer aided design (CAD) (Ozer, 2000; Zhou et al., 2007; Lehrer \& Behnam, 2009; Kawakami et al., 2011; Asimakopoulos \& Dix, 2013; Peng et al., 2014; Presutti Junior, 2003; Nazari-Shirkouhi, 2015; Wang, 2015; Tontini, 2016; Miyatake et al., 2016; Wu et al., 2016). In this ICT's list we did not include Product Data Management (PDM) and Product Lifecycle Management (PLM), two specific tools of the NPD activities, since both tools are more characterized as integration tools (Oh et al., 2001; Prashanth \& Venkataram, 2017). Therefore, so that we could avoid possible overlap with other tools, we opted for not including neither PDM nor PLM. PDM was not included because most of the CAD/CAE tools today already include PDM options on its system (Oh et al., 2001; Prashanth \& Venkataram, 2017). Hence, we understand that it could cause a redundancy in our analysis. PLM was not included because it acts more as an integration tool for other 1CT tools rather than one that exerts a specific role on the NPD process (Deuter \& Rizzo, 2016; Prashanth \& Venkataram, 2017). In this sense, we opted to study the operational tools, which can be integrated by a PLM system. The Collaborative Practices [COLLAB_PRACT] construct, in turn, was represented by four items (Table 2): (i) customer involvement in the NPD; (ii) long relationships with suppliers; (iii) frequent information sharing with suppliers and (iv) delivery to suppliers by pull system (Ragatz et al., 1997; Flynn et al., 2010; Wong et al., 2013; Peng et al., 2014). Finally, the response variable of the model, NPD Performance, was measured through the level of customer satisfaction [SATISFACTION] as a single variable based on Durmuşoğlu \& Barczak (2011), Koufteros et al. (2007) and Silva et al. (2012). 
Table 2. Items of the composite scales.

\begin{tabular}{|c|c|c|}
\hline Constructs & Main concept of the question (item) & Main references used for the item \\
\hline \multirow{4}{*}{$\begin{array}{l}\text { Collaborative Practices } \\
\text { (COLLAB_PRACT) }\end{array}$} & Customer involvement in the NPD & Flynn et al. (2010); Peng et al. (2014); Wong et al. (2013) \\
\hline & Long relationships with suppliers & $\begin{array}{l}\text { Flynn et al. (2010); Peng et al. (2014); Ragatz et al. } \\
\text { (1997); Wong et al. (2013) }\end{array}$ \\
\hline & Frequent information sharing with suppliers & $\begin{array}{l}\text { Flynn et al. (2010); Peng et al. (2014); Ragatz et al. } \\
\text { (1997); Wong et al. (2013) }\end{array}$ \\
\hline & Delivery to suppliers by pull system & $\begin{array}{l}\text { Flynn et al. (2010); Peng et al. (2014); Ragatz et al. } \\
\text { (1997); Wong et al. (2013) }\end{array}$ \\
\hline \multirow{11}{*}{$\begin{array}{l}\text { Information and } \\
\text { Communication Technology } \\
\text { (ICT) }\end{array}$} & Electronic Data Interchange (EDI) & Ragatz et al. (1997) \\
\hline & Vendor Managed Inventory (VMI) & Lehrer \& Behnam (2009) \\
\hline & Customer Relationship Management (CRM) & Kawakami et al. (2011); Nazari-Shirkouhi (2015) \\
\hline & Business Intelligence (BI) & Wang (2015) \\
\hline & E-procurement & Presutti Junior (2003) \\
\hline & Internet / Intranet & Ozer (2000) \\
\hline & Supplier Relationship Management (SRM) & Nazari-Shirkouhi (2015) \\
\hline & Computer Integrated Manufacturing (CIM) & Zhou et al. (2007) \\
\hline & Forecast Demand Systems & Asimakopoulos \& Dix (2013); Lehrer \& Behnam (2009) \\
\hline & Online Sales Systems & Miyatake et al. (2016); Tontini (2016) \\
\hline & $\begin{array}{c}\text { Computer-Aided Design (CAD) / Computer-Aided } \\
\text { Engineering (CAE) }\end{array}$ & Kawakami et al. (2011); Peng et al. (2014) \\
\hline
\end{tabular}

The questions for the [1CT_TOOLS] and [COLLAB_PRACT] constructs were measured by asking the degree of adoption of each practice/ICT tool at the respondent's business unit using a five-point likert scale, with the description of the highest ( $5=$ fully adopted), lowest ( $1=$ not adopted) and center ( $3=$ partially adopted) values. On the other hand, [SATISFACTION] was measured also using five-point Likert scale by asking the change of the performance metric over the last 5 years. The scale was ranged from 1 (worsened significantly) to 5 (improved significantly), and centered at 3 (did not changed). We have summarized the variables and references in Table 2.

We also included two control variables (i) Company size [Dummy_Size] and NPD Complexity [Dummy_Complexity] in our regression models, following prior research that demonstrated their influence on the NPD process and on the use of ICT tools. In this way, firstly we considered a dummy variable for firm's size (number of employees) classifying it into two categories as showed in Table $1(0=$ small/medium; $1=$ large $)$. As indicated by previous literature, firm's size can affect the intensity in which collaborative activities are adopted, since larger firms may have more financial and human resources to invest in these activities (Koufteros et al., 2007; Pavlou \& El Sawy, 2010). Secondly, NPD complexity was measured by asking to respondents the most usual degree of complexity of product developed in their company, using a three-point scale ( 1 = low complexity; 2 = medium complexity and 3 = high complexity). Similarly, we considered this second variable due to the fact that prior authors have demonstrated that the relationship between ICT tools, NPD practices and collaboration are affected by NPD project complexity. For instance, as product complexity increases, the number of product components and their interfaces may also quickly increase, leading to an increased amount of design information that must be processed (Peng et al., 2014; Silva, 2014).

\subsection{Common method variance}

We followed complementary techniques suggested by Podsakoff et al. (2003) to reduce the risk of common method bias. Firstly, we randomized the questions in order to avoid the respondent to directly associate variables that could be expected to have a relationship. In addition, we sent our questionnaire to respondents who were familiar with the jargon in order to avoid misconceptions and misinterpretations. Thus, it was necessary for our respondents to have a certain level of familiarity with the NPD process. Finally, we calculated the Harman's single-factor test with an exploratory factor analysis to address common method bias (Podsakoff et al., 2003), resulting into a first factor that comprehended only 34\% of the observed variance. This test indicated that common method bias could be not a problem in our sample, since there was no single factor accounting for the majority of the variance in the model. 


\subsection{Measure validity and reliability}

For the constructs ICT_TOOLS and COLLAB_PRACT we validated unidimensionality by means of a confirmatory factor analysis (CFA) with STATA $13.0^{\circledR}$. This test indicated acceptable fitness of each multi-item construct proposed [1CT_TOOLS]: $\mathrm{CFI}=0.963$, RMSEA $=0.050$; [COLLAB_PRACT] $: \mathrm{CF} 1=0.931$, RMSEA $=0.181$. All items were strongly loaded on their constructs (factor loading $p$-value $<0.01$ ) in the two models. Also, the construct reliability (Cronbach's alpha) exceeded the usual acceptable level of 0.7 (Hair Junior et al., 2009).

We also tested discriminant validity, as indicated by Bagozzi et al. (1991), who suggested a series of two-factor model estimation. For each pair of possible constructs, we performed two CFA and compared their goodness of fit. In the first model we restricted the correlation between the two constructs to unity while in the second model we freed this restriction and calculated the goodness of fit for the original constructs. In this test the overall results showed discriminant validity $\left(\Delta \chi^{2}>3.84\right.$, $p$-value $\left.<0.05\right)$. The correlation matrix for all main variables and their respective means as well as standard deviations are shown in Table 3.

Table 3. Bivariate correlation matrix with descriptive scales and reliability estimates.

\begin{tabular}{|c|c|c|c|c|c|c|}
\hline & & Mean & S.D. & 1 & 2 & 3 \\
\hline 1 & SATISFACION & 3.86 & 0.78 & --- & & \\
\hline 2 & 1CT_TOOLS & 2.74 & 0.81 & $0.229^{* * *}$ & --- & \\
\hline \multirow[t]{3}{*}{3} & COLLAB_PRACT & 2.96 & 0.86 & $0.272^{* * * *}$ & $0.669^{* * * *}$ & --- \\
\hline & & Cronbach's Alpha & & $\mathrm{N} / \mathrm{A}$ & 0.86 & 0.76 \\
\hline & & Composite Reliability & & $\mathrm{N} / \mathrm{A}$ & 0.87 & 0.74 \\
\hline
\end{tabular}

**** $p<0.01$.

\section{Results}

For the data analysis we used OLS regression calculated in SPSS ${ }^{\circledR}$. The data analysis was performed in two steps, as shown in Table 4. Thus, we firstly analyzed the impact of the ICT_TOOLS on COLLAB_PRACT (H2) and then we analyzed the impact of both ICT_TOOLS and COLLAB_PRACT on SATISFACTION (H1 and H3 respectively) in order to test whether or not there is a mediating effect between the variables (Baron \& Kenny, 1986). In other words, we propose a sequence of relationships in which 1CT_TOOLS supports COLLAB_PRACT (H1), and this variable exert an impact on SATISFACTION $(\mathrm{H} 2)$, being, therefore, the variable COLLAB_PRACT the mediator of this model. We proceeded with the regression in a hierarchical way, by adding the variables sequentially. Thus, we firstly started with the control variables and then we added each explanatory variable. The improved models were statically significant for both COLLAB_PRACT $(F=24.52, p<0.01)$ and SATISFACTION $(F=2.644, p<0.05)$ and they explained $47.5 \%$ and $7.3 \%$ of the total variance (Adjusted $\mathrm{R}^{2}$ ), respectively.

Table 4. The impact of ICT tools adoption on Collaborative Practices (COLLAB_PRACT).

\begin{tabular}{|c|c|c|c|c|c|}
\hline \multirow{3}{*}{ Independent variables } & \multicolumn{5}{|c|}{ Dependent variables } \\
\hline & \multicolumn{2}{|c|}{ COLLAB_PRACT } & \multicolumn{3}{|c|}{ SATISFACTION } \\
\hline & Model 1a & Model 2a & Model 1b & Model 2b & Model 3b \\
\hline Dummy__LwComp (control) & $-0.434^{* *}$ & -0.210 & 0.203 & $0.288^{*}$ & $0.330^{*}$ \\
\hline Dummy_MediumComp (control) & 0.241 & $0.271^{*}$ & 0.307 & 0.319 & 0.264 \\
\hline Dummy_Size (control) & 0.319 & -0.129 & 0.044 & -0.068 & -0.042 \\
\hline ICT_TOOLS & --- & $0.568^{* * *}$ & --- & $0.216^{* * *}$ & 0.101 \\
\hline COLLAB_PRACT & --- & --- & --- & --- & $0.174^{*}$ \\
\hline F-values & $4.01^{* *}$ & $24.52^{* * *}$ & 0.865 & $2.556^{* *}$ & $2.644^{* *}$ \\
\hline $\mathrm{R}^{2}$ & 0.106 & 0.495 & 0.025 & 0.093 & 0.118 \\
\hline Adj. $R^{2}$ & 0.08 & 0.475 & -0.004 & 0.056 & 0.073 \\
\hline
\end{tabular}

${ }^{*} p<0.1 ;{ }^{* *} p<0.05 ;{ }^{* * *} p<0.01$.

For the mediation test, the first condition that must be attended is that the independent variable ICT_TOOLS must exert a significant effect on the dependent variable SATISFACTION, which was successfully attended, as shown in Model $2 \mathrm{~b}$ of Table $4(\mathrm{~B}=0.216, \mathrm{p}<0.01)$. This first test corroborates that, in fact, ICT tools support the NPD performance in terms of customer satisfaction, even when there is only a little contribution on it (i.e. the model explains 5.6\% of the total variance). The second test consists in assessing whether or not the 
independent variable ICT_TOOLS exert a significant impact on the mediator COLLAB_PRACT, which is represented by our hypothesis $\mathrm{H} 2$. Our results in Table 4 show that in Model 2a $\mathrm{H} 2$ was supported, i.e. there is indeed a significant effect $(B=0.568, p<0.01)$. Moreover, Model 2a indicates that this relationship explains $49.5 \%$ of the variance, suggesting that ICT tools implementation is one of the most important aspects necessary for a successful collaboration. Finally, the third step that must be attended is that the increment of the mediator variable COLLAB_PRACT in Model $2 \mathrm{~b}$ should improve the model and that there must be a significant mediating effect, which was achieved in Model 3b. As shown in this last model, our results validated hypothesis $\mathrm{H} 3$ since COLLAB_PRACT exerts a positive effect on SATISFACTION $(B=0.174, p<0.1)$. Moreover, our results suggested that there is a complete mediation of COLLAB_PRACT when this variable is added to the model. Finally, the independent variable ICT_TOOLS does not exert a significant effect on the performance metric SATISFACTION, which is one of the requisites for a complete mediation (Baron \& Kenny, 1986).

\section{Discussion}

Our results help to better understand different aspects of the ICT tools adoption and their use on supporting collaborative practices and the impact of this adoption on customer satisfaction, as an indicator of NPD performance. Firstly, we provided empirical evidence about the importance of involving customer and suppliers in the NPD process, specifically regarding how to improve the level of customer satisfaction. This supports prior findings of Büyüközkan \& Arsenyan (2012) and Silva (2014) who suggested that collaborative NPD is a way to improve the efficiency and effectiveness of the companies' product development process. At the same time, while prior quantitative works in this field were more focused on other NPD performance indicators, such as market share improvement (Ettlie \& Pavlou, 2006; Barczak et al., 2007), product quality (Koufteros et al., 2007), reduction of cycle time and costs (Banker et al., 2006), among others; we focused specifically on studying customer satisfaction level as a complementary point of view of NPD success. In addition, our study demonstrated that ICT tools are essential to support such collaborative practices - even in an emerging economy, such as the Brazilian one - since they facilitate communication and cooperation, as defended by other authors: Barczak et al. (2008), and Peng et al. (2014). Therefore, even with some streams of research defending the importance of face-to-face collaboration (Johnsen, 2009; Gonçalves et al., 2014), our results suggest another point of view, arguing that, ICT tools may reduce the negative impact caused by physical distance in NPD projects and possibly enhance the potential collaboration among partners. This is especially important in the Brazilian case, since it has most of its innovation efforts performed by multinational companies that have strong level of interaction with their headquarters, usually located in developed countries (Kannebley Júnior et al., 2005; Queiroz \& Carvalho, 2005; Urraca-Ruiz \& Amorim, 2010).

Our regression model showed a significant effect of collaborative practices on customer satisfaction, but it also indicated that only a small percentage of such a relationship in Brazilian companies can be explained by collaboration (i.e. we obtained a low R-square value). In line with recent findings of Frank et al. (2016), in their study of Brazilian innovation, this small percentage may be attributed to the fact that Brazilian companies have not made yet a strong effort to innovate based on collaboration. Moreover, Brazilian firms are not used to look for software acquisition strategies as a possible infrastructure to support and enhance such collaboration. Even the supply chain management is still incipient in the manufacturing sectors of this country (Marodin et al., 2016), which reinforces the weak external collaboration for NPD. Therefore, our empirical results may indicate that, in the Brazilian context, companies that work in collaboration, support their NPD activities with few technological tools, which could difficult such collaboration. Consequently, we can propose as a possible explanation that the relative low, but significant impact, that collaboration exerts on NPD performance may be, in part, due to the lack of a strong technological base. Moreover, as our sequential model shows, ICT may enhance collaboration which yields a better performance in terms of customer satisfaction.

Additionally, our results show that the investment in ICT tools cannot be done with the expectation of obtaining a better customer satisfaction without considering the adoption of collaborative practices on the process itself. This means that, as we demonstrated, the adoption of collaborative practices is a mediator between the use of ICT tools and the customer satisfaction and, therefore, companies should focus on this sequence to obtain better levels of customer satisfaction. In other words, those companies that are using ICT tools without a collaborative context on their NPD process are not taking fully advantage of them and eventually loosing several benefits that these tool promote. In this sense, Frank et al. (2016) and Cortimiglia et al. (2012) indicated that the acquisition and use of ICT tools is a valued innovation activity by Brazilian companies and a strategy that has been growing over the last decade. They also showed that investments in these technologies are more focused on automatizing operational routines for the improvement of basic infrastructure instead of investing in 
advanced ICT tools that may enable an opportunity to transform their business and give them a real competitive differentiation. According to our findings, the successful use of ICT tools in collaborative NPD depends on the NPD process organization itself and the way that suppliers and customers are involved along this process, reinforcing results of Chen (2007), who affirmed that in the internal firm's context, ICT tools can deliver a better NPD performance, if primarily mediated by effects of cross-functional team interaction.

Undoubtedly, the use of ICT tools enables potential significant improvements in NPD activities of companies. Ultimately, it should be noted that the mere use of a technology may not be enough, because the only use of the ICT assets themselves do not create value for the company. Therefore, the company should combine ICT tools with other non-ICT resources (Marion et al., 2014). The communication and information socialization are mediated by the collaboration (Xu et al., 2017) and these activities frequently occurs through ICT when there is a long distance between the partners. Therefore, collaborative practices should be a primary concern in companies and after they are well-established and coordinated, companies should plan the implementation of ICT tools with a clear vision about how this can help to improve the collaboration with customers and suppliers and how these tools can be included in the NPD activities (Reid et al., 2016).

Another interesting finding regards the level of product complexity as a control variable in our model. According to our findings, the more complex the product is, the more collaboration companies will pursue with their stakeholders. On the other hand, the lower the level of product complexity, the higher the level customer satisfaction the company seems to achieve. The first contribution (complexity to collaboration) is aligned with prior findings reported by Peng et al. (2014), whose work demonstrated that ICT tools and collaboration are stronger when product complexity is greater, and with Park \& Lee (2014), who demonstrated a positive relationship between project complexity and partner's dependency. On the other hand, regarding customer satisfaction and product complexity, our results indicate that Brazilian companies find difficult to develop high innovative products, as previously stated by do Couto e Silva Neto et al. (2013) and Frank et al. (2016). Only products with low complexity were, in our results, positively associated to customer satisfaction. This may reinforce the relevant role of stakeholders, such as suppliers and customers in the NPD process, in order to improve the capacity of developing complex products well aligned with the needs of customers.

\section{Conclusions}

We presented a quantitative survey about the contribution of ICT tools to support collaborative NPD practice and the impact that this has on one aspect of the NPD performance, which is customer satisfaction. We investigated the Brazilian emerging market, where the ICT tools has been increasingly adopted over the last decade. We showed that there is a sequential positive effect where collaborative NPD practices mediate the relationship between ICT tools and customer satisfaction as a metric of NPD performance.

In this sense, the main contribution of this paper consists in the following aspects: (i) We addressed an emerging economy, while most of the studies about the use of ICT tools are based on companies from developed countries where the technological development is usually stronger and more mature. Moreover, our study investigated the Brazilian industry, as a Latin America emerging economy, which has its technological development being less studied, when compared to other emerging economies, such as the Chinese and Indian ones; (ii) We expanded the current understanding about the relationship between ICT tools, collaborative practices for NPD activities, and NPD performance. This has been done by studying the influence of different variables that have not been addressed by other works. For instance, in terms of NPD performance, we used customer satisfaction, in order to consider a market perspective on the impact of such variable. We also investigated ICT tools individually and grouped them in a single construct, instead of only investigating a general concept of ICT tools as previously done in the literature. Therefore, these are examples about our complementary contribution for the theoretical understanding of this issue; (iii) Our results showed that the set of ICT tools we considered are mediated by collaborative practices. This indicates that the involvement of suppliers and customers in different activities of the NPD process contributes to increase the level of customer satisfaction, providing evidences that a constant feedback with these stakeholders may help companies to better understand costumers needs in terms of product requirements and specifications. We also provided evidence about the use of ICT as a support for collaboration, since the contribution of these tools enhance the success of NPD projects, from the aspect of customer satisfaction, by promoting effective communication among companies and other partners, reinforcing that investing in ICT tools and developing collaboration are complementary efforts and, therefore, they should be made together.

Finally, this study has some limitations that open opportunities for future research. Firstly, our study analyzed collaborative practices but we did not differentiate the types of collaboration. The literature on suppliers' involvement in NPD could also help to introduce some types of collaboration (e.g white, grey and black box 
configurations of collaboration), which could enhance the understanding of the dynamic relationship between ICT and collaboration (Ayala et al., 2017). Further, our research was applied in the context of Brazilian companies; hence it will be interesting to compare these results with those from companies based in other emerging countries since this would support the identification of best practices and opportunities for improvement. Moreover, we performed a cross-industry study, but sectorial characteristics should be also a matter for future research, since they can present different needs regarding ICT tools and collaboration intensity. The value chain position can also be a factor influencing the characteristics of ICT use and collaboration intensity. These are some additional concerns that future studies should address.

\section{Contributions for practitioners}

Our results bring also contributions for practitioners from both the NPD and ICT management field. Our study indicates that the implementation of advanced ICT tools, only, is not enough to achieve higher levels of customer satisfaction. In this sense, managers should firstly be focused on strengthening the relationship between stakeholders through well-defined processes. Thus, only after such an effort, they would be able to establish a support based on ICT tools that could be really beneficial to the NPD process itself. In addition, the acquisition of technologies should consider different strategic levels of the company and not only the operational level, as commonly observed in Brazilian companies.

\section{References}

Ahuja, V., Yang, J., \& Shankar, R. (2009). Benefits of collaborative ICT adoption for building project management. Construction Innovation, 9(3), 323-340. http://dx.doi.org/10.1108/14714170910973529.

Ajzen, l. (1991). The theory of planned behavior. Organizational Behavior and Human Decision Processes, 50(2), 179-211. http://dx.doi. org/10.1016/0749-5978(91)90020-T.

Asimakopoulos, S., \& Dix, A. (2013). Forecasting support systems technologies-in-practice: a model of adoption and use for product forecasting. International Journal of Forecasting, 29(2), 322-336. http://dx.doi.org/10.1016/j.ijforecast.2012.11.004.

Ayala, N. F., Paslauski, C. A., Ghezzi, A., \& Frank, A. G. (2017). Knowledge sharing dynamics in service suppliers' involvement for servitization of manufacturing companies. International Journal of Production Economics, 193, 538-553. http://dx.doi.org/10.1016/j. ijpe.2017.08.019.

Backer, K., López-Bassols, V., \& Martinez, C. (2008). Open innovation in a global perspective: what do existing data tell us? (OECD Science, Technology and Industry Working Papers, No. 2008/04). Paris: OECD Publishing. http://doi.org/10.1787/230073468188.

Bagozzi, R. Y. 1., Yi, Y., \& Phillips, L. W. (1991). Assessing construct validity in organizational research. Administrative Science Quarterly, 36(3), 421-458. http://dx.doi.org/10.2307/2393203.

Banker, R. D., Bardhan, 1., \& Asdemir, 0. (2006). Understanding the impact of collaboration software on product design and development. Information Systems Research, 174), 352-373. http://dx.doi.org/10.1287/isre.1060.0104.

Barczak, G., Hultink, E. J., \& Sultan, F. (2008). Antecedents and consequences of information technology usage in NPD: a comparison of Dutch and U.S. companies. Journal of Product Innovation Management, 25(6), 620-631. http://dx.doi.org/10.1111/j.15405885.2008.00326.x.

Barczak, G., Sultan, F., \& Hultink, E. J. (2007). Determinants of IT usage and new product performance. Journal of Product Innovation Management, 24(6), 600-613. http://dx.doi.org/10.1111/j.1540-5885.2007.00274.x.

Baron, R. M., \& Kenny, D. A. (1986). The moderator-mediator variable distinction in social psychological research: conceptual, strategic, and statistical considerations. Journal of Personality and Social Psychology, 51(6), 1173-1182. http://dx.doi.org/10.1037/00223514.51.6.1173. PMid:3806354.

Bombaywala, M., \& Riandita, A. (2015). Stakeholders' collaboration on innovation in food industry. Procedia: Social and Behavioral Sciences, 169, 395-399. http://dx.doi.org/10.1016/j.sbspro.2015.01.325.

Bryan, R., Rudolf, J., \& Daekwan, R. S. (2014). The impact of technological, organizational and environmental characteristics on electronic collaboration and relationship performance in international customer-supplier relationships. Information \& Management, 51(7), 854-864. http://dx.doi.org/10.1016/j.im.2014.08.002.

Büyüközkan, G., \& Arsenyan, J. (2012). Collaborative product development: a literature overview. Production Planning and Control, 23(1), 47-66. http://dx.doi.org/10.1080/09537287.2010.543169.

Chang, J. (2017). The effects of buyer-supplier's collaboration on knowledge and product innovation. Industrial Marketing Management, 65, 129-143. http://dx.doi.org/10.1016/j.indmarman.2017.04.003.

Chen, C.-J. (2007). Information technology, organizational structure, and new product development: the mediating effect of cross-functional team interaction. IEEE Transactions on Engineering Management, 54(4), 687-698. http://dx.doi.org/10.1109/TEM.2007.906831.

Chesbrough, H. W. (2006). Open innovation: the new imperative for creating and profiting from technology. Boston: Harvard Business Press.

Consoli, D. (2012). Literature analysis on determinant factors and the impact of ICT in SMEs. Procedia: Social and Behavioral Sciences, 62, 93-97. http://dx.doi.org/10.1016/j.sbspro.2012.09.016.

Cortimiglia, M. N., Frank, A. G., \& Miorando, R. F. (2012). ICT trends in Brazil. IT Professional, 14(4), 31-38. http://dx.doi.org/10.1109/ MITP.2012.70. 
Couto e Silva Neto, F. C., Santos, U. P., Parreiras Oliveira, V., Castro, P. G., Melo Franco, L. T., \& Negri, F. (2013). Patterns of interaction between national and multinational corporations and Brazilian universities/public research institutes. Science \& Public Policy, 40(3), 281-292. http://dx.doi.org/10.1093/scipol/scs105.

Delone, W. H., \& McLean, E. R. (1992). Information systems success: the quest for the dependent variable. Information Systems Research, 3(1), 60-95. http://dx.doi.org/10.1287/isre.3.1.60.

Deuter, A., \& Rizzo, S. (2016). A critical view on PLM/ALM convergence in practice and research. Procedia Technology, 26, 405-412. http://dx.doi.org/10.1016/j.protcy.2016.08.052.

Dong, J. Q., \& Yang, C.-H. (2015). Information technology and organizational learning in knowledge alliances and networks: evidence from U.S. pharmaceutical industry. Information \& Management, 52(1), 111-122. http://dx.doi.org/10.1016/j.im.2014.10.010.

Durmuşoğlu, S. S., \& Barczak, G. (2011). The use of information technology tools in new product development phases: analysis of effects on new product innovativeness, quality, and market performance. Industrial Marketing Management, 40(2), 321-330. http:// dx.doi.org/10.1016/j.indmarman.2010.08.009.

Ettlie, J. E., \& Pavlou, P. A. (2006). Technology-based new product development partnerships. Decision Sciences, 37(2), 117-147. http:// dx.doi.org/10.1111/j.1540-5915.2006.00119.x.

Flynn, B. B., Huo, B., \& Zhao, X. (2010). The impact of supply chain integration on performance: a contingency and configuration approach. Journal of Operations Management, 28(1), 58-71. http://dx.doi.org/10.1016/j.jom.2009.06.001.

Frank, A. G., Cortimiglia, M. N., Ribeiro, J. L. D., \& Oliveira, L. S. (2016). The effect of innovation activities on innovation outputs in the Brazilian industry: Market-orientation vs. technology-acquisition strategies. Research Policy, 45(3), 577-592. http://dx.doi. org/10.1016/j.respol.2015.11.011.

Frank, A. G., Ribeiro, J. L. D., \& Echeveste, M. E. (2015). Factors influencing knowledge transfer between NPD teams: a taxonomic analysis based on a sociotechnical approach. $R \& D$ Management, 45(1), 1-22. http://dx.doi.org/10.1111/radm.12046.

Frank, A., \& Echeveste, M. (2012). Knowledge transfer between NPD project teams: a method for the identification of improvement opportunities. International Journal of Quality \& Reliability Management, 29(3), 242-264. http://dx.doi.org/10.1108/02656711211216126.

Gonçalves, P., Ferreira, L., Gonçalves, J., Putnik, G. D., \& Cruz-Cunha, M. M. (2014). Direct communication versus virtual communication in virtual teams. Procedia Technology, 16, 3-10. http://dx.doi.org/10.1016/j.protcy.2014.10.062.

Gono, S., Harindranath, G., \& Özcan, G. B. (2016). The adoption and Impact of ICT in South African SMEs. The Strategic Impact of Information Technology Deployment, 1(734), 717-734.

Griffith, T. L., \& Sawyer, J. E. (2006). Supporting technologies and organizational practices for the transfer of knowledge in virtual environments. Group Decision and Negotiation, 15(4), 407-423. http://dx.doi.org/10.1007/s10726-006-9048-4.

Gu, S., \& Lundvall, B. Å. (2006). Introduction: China's innovation system and the move towards harmonious growth and endogenous innovation. Innovation, 8(1-2), 1-26. http://dx.doi.org/10.5172/impp.2006.8.1-2.1.

Hair Junior, J. F., Black, W. C., Babin, B. J., \& Anderson, R. E. (2009). Multivariate data analysis (6th ed.). New York: Prentice-Hall International.

Hemetsberger, A., \& Godula, G. (2007). Integrating expert customers in new product development in industrial business-virtual routes to success. Innovative Marketing, 3(3), 28-33.

Isaksson, A. J., Harjunkoski, 1., \& Sand, G. (2017). the impact of digitalization on the future of control and operations. Computers \& Chemical Engineering. http://dx.doi.org/10.1016/j.compchemeng.2017.10.037.

Johnsen, T. E. (2009). Supplier involvement in new product development and innovation: Taking stock and looking to the future. Journal of Purchasing and Supply Management, 15(3), 187-197. http://dx.doi.org/10.1016/j.pursup.2009.03.008.

Kannebley Júnior, S., Porto, G. S., \& Pazello, E. T. (2005). Characteristics of Brazilian innovative firms: An empirical analysis based on PINTEC: industrial research on technological innovation. Research Policy, 34(6), 872-893. http://dx.doi.org/10.1016/j.respol.2005.04.003.

Kawakami, T., Durmuşoğlu, S. S., \& Barczak, G. (2011). Factors influencing information technology usage for new product development: the case of japanese companies. Journal of Product Innovation Management, 28(6), 833-847. http://dx.doi.org/10.1111/j.15405885.2011.00848.x.

Kim, Y., Hall, H., \& Hall, H. (2011). Technology adoption and use theory review for studying scientists ' continued use of cyberinfrastructure. ASSIST, 48(1), 1-10. https://doi.org/10.1002/meet.2011.14504801197.

Koufteros, X. A., Edwin Cheng, T. C., \& Lai, K. H. (2007). "Black-box" and "gray-box" supplier integration in product development: antecedents, consequences and the moderating role of firm size. Journal of Operations Management, 25(4), 847-870. http://dx.doi. $\operatorname{org} / 10.1016 /$ j.jom.2006.10.009.

La Rocca, A., Moscatelli, P., Perna, A., \& Snehota, l. (2016). Industrial Marketing Management Customer involvement in new product development in B2B : The role of sales. Industrial Marketing Management, 58, 45-57. http://dx.doi.org/10.1016/j.indmarman.2016.05.014.

Laage-Hellman, J., Lind, F., \& Perna, A. (2014). Customer Involvement in Product Development: An Industrial Network Perspective. Journal of Business-To-Business Marketing, 21(4), 257-276. http://dx.doi.org/10.1080/1051712X.2014.979594.

Lakemond, N., Berggren, C., \& Weele, A. (2006). Coordinating supplier involvement in product development projects: a differentiated coordination typology. $R \& D$ Management, 36(1), 55-66. http://dx.doi.org/10.1111/j.1467-9310.2005.00415.x.

Langner, B., \& Seidel, V. P. (2009). Collaborative concept development using supplier competitions: Insights from the automotive industry. Journal of Engineering and Technology Management, 26(1-2), 1-14. http://dx.doi.org/10.1016/j.jengtecman.2009.03.007.

Lapierre, J., \& Denier, A. (2005). ICT adoption and moderating effects of institutional factors on salesperson's communication effectiveness: a contingency study in high-tech industries. Technovation, 25(8), 909-927. http://dx.doi.org/10.1016/j.technovation.2004.01.012.

Lehrer, M., \& Behnam, M. (2009). Modularity vs programmability in design of international products: beyond the standardizationadaptation tradeoff? European Management Journal, 27(4), 281-292. http://dx.doi.org/10.1016/j.emj.2009.01.003.

Li, M., Zheng, X., \& Zhuang, G. (2017). Information technology-enabled interactions, mutual monitoring, and supplier-buyer cooperation: a network perspective. Journal of Business Research, 78, 268-276. http://dx.doi.org/10.1016/j.jbusres.2016.12.022. 
Marion, T. J., Barczak, G., \& Hultink, E. J. (2014). Do social media tools impact the development phase? An exploratory study. Journal of Product Innovation Management, 31(S1), 18-29. http://dx.doi.org/10.1111/jpim.12189.

Marodin, G., Frank, A. G., Tortorella, G., \& Saurin, T. A. (2016). Contextual factors and lean production implementation in the Brazilian automotive supply chain. Supply Chain Management, 21(4), 417-432. http://dx.doi.org/10.1108/SCM-05-2015-0170.

Marra, M., Ho, W., \& Edwards, J. S. (2012). Supply chain knowledge management: a literature review. Expert Systems with Applications, 39(5), 6103-6110. http://dx.doi.org/10.1016/j.eswa.2011.11.035.

McGrath, K., \& Maiye, A. (2010). The role of institutions in ICT innovation: learning from interventions in a Nigerian e-government initiative. Information Technology for Development, 16(4), 260-278. http://dx.doi.org/10.1080/02681102.2010.498408.

Miyatake, K., Nemoto, T., Nakaharai, S., \& Hayashi, K. (2016). Reduction in consumers' purchasing cost by online shopping. Transportation Research Procedia, 12, 656-666. http://dx.doi.org/10.1016/j.trpro.2016.02.019.

Montoya, M. M., Massey, A. P., Hung, Y. C., \& Crisp, C. B. (2009). Can you hear me now? Communication in virtual product development teams. Journal of Product Innovation Management, 26(2), 139-155. http://dx.doi.org/10.1111/j.1540-5885.2009.00342.x.

Mu, J., Thomas, E., Peng, G., \& Di Benedetto, A. (2017). Strategic orientation and new product development performance: the role of networking capability and networking ability. Industrial Marketing Management, 64, 187-201. http://dx.doi.org/10.1016/j. indmarman.2016.09.007.

Nazari-Shirkouhi, S. (2015). Investigating the effects of customer relationship management and supplier relationship management on new product development. Tehni $\square$ ki vjesnik, 22(1), 191-200. http://dx.doi.org/10.17559/TV-20140623130536.

Ngwenyama, 0., \& Morawczynski, 0. (2009). Factors affecting ICT expansion in emerging economies: analysis of ict infrastructure expansion in five latin american countries. Information Technology for Development, 15(4), 237-258. http://dx.doi.org/10.1002/itdj.20128.

Nunes, M., Pereira, A. C., \& Alves, A. C. (2017). Smart products development approaches for Industry 4.0. Procedia Manufacturing, 13, 1215-1222. http://dx.doi.org/10.1016/j.promfg.2017.09.035.

Oh, Y., Han, S., \& Suh, H. (2001). Mapping product structures between CAD and PDM systems using UML. Computer Aided Design, 33(7), 521-529. http://dx.doi.org/10.1016/S0010-4485(01)00051-3.

Ozer, M. (2000). Information technology and new product development. Industrial Marketing Management, 29(5), 387-396. http:// dx.doi.org/10.1016/S0019-8501(99)00060-7.

Park, J.-G., \& Lee, J. (2014). Knowledge sharing in information systems development projects: explicating the role of dependence and trust. International Journal of Project Management, 32(1), 153-165. http://dx.doi.org/10.1016/j.jproman.2013.02.004.

Pavlou, P. A., \& El Sawy, O. A. (2010). The "third hand": IT-enabled competitive advantage in turbulence through improvisational capabilities. Information Systems Research, 21(3), 443-471. http://dx.doi.org/10.1287/isre.1100.0280.

Peng, D. X., Heim, G. R., \& Mallick, D. N. (2014). Collaborative product development: the effect of project complexity on the use of information technology tools and new product development practices. Production and Operations Management, 23(8), 1421 -1438. http://dx.doi.org/10.1111/j.1937-5956.2012.01383.x.

Petersen, K. J., Handfield, R. B., \& Ragatz, G. L. (2005). Supplier integration into new product development: coordinating product, process and supply chain design. Journal of Operations Management, 23(3-4), 371-388. http://dx.doi.org/10.1016/j.jom.2004.07.009.

Podsakoff, P. M., Mackenzie, S. B., Lee, J.-Y., \& Podsakoff, N. P. (2003). Common method biases in behavioral research: a critical review of the literature and recommended remedies. The Journal of Applied Psychology, 88(5), 879-903. http://dx.doi.org/10.1037/00219010.88.5.879. PMid:14516251.

Prashanth, B. N., \& Venkataram, R. (2017). Development of modular integration framework between PLM and ERP systems. Materials Today: Proceedings, 4(2), 2269-2278. http://dx.doi.org/10.1016/j.matpr.2017.02.075.

Presutti Junior, W. D. (2003). Supply management and e-procurement: creating value added in the supply chain. Industrial Marketing Management, 32(3), 219-226. http://dx.doi.org/10.1016/S0019-8501(02)00265-1.

Primo, M. A., \& Amundson, S. D. (2002). An exploratory study of the effects of supplier relationships on new product development outcomes. Journal of Operations Management, 20(1), 33-52. http://dx.doi.org/10.1016/S0272-6963(01)00080-8.

Queiroz, S., \& Carvalho, R. D. Q. (2005). Empresas multinacionais e inovação tecnológica no Brasil. São Paulo em Perspectiva, 19(2), 51-59. http://dx.doi.org/10.1590/S0102-88392005000200005.

Ragatz, G. L., Handfield, R. B., \& Petersen, K. J. (2002). Benefits associated with supplier integration into new product development under conditions of technology uncertainty. Journal of Business Research, 55(5), 389-400. http://dx.doi.org/10.1016/S0148-2963(00)00158-2.

Ragatz, G. L., Handfield, R. B., \& Scannell, T. V. (1997). Success factors for integrating suppliers into new product development. Journal of Product Innovation Management, 14(3), 190-202. http://dx.doi.org/10.1016/S0737-6782(97)00007-6.

Reid, M., Hultink, E. J., Marion, T., \& Barczak, G. (2016). The impact of the frequency of usage of IT artifacts on pre-development performance in the NPD process. Information \& Management, 53(4), 422-434. http://dx.doi.org/10.1016/j.im.2015.10.008.

Roztocki, N., \& Weistroffer, H. R. (2015). Information and communication technology in transition economies: an assessment of research trends. Information Technology for Development, 21(3), 330-364. http://dx.doi.org/10.1080/02681102.2014.891498.

Santos, K., Loures, E., Piechnicki, F., \& Canciglieri, 0. (2017). Opportunities assessment of product development process in industry 4.0. Procedia Manufacturing, 11, 1358-1365. http://dx.doi.org/10.1016/j.promfg.2017.07.265.

Silva, C. (2014). The role of ICT in collaborative product development: a conceptual model based on information processing theory. International Journal of Innovation, Management and Technology, 5(1), 43-49. http://dx.doi.org/10.7763/1JIMT.2014.V5.484.

Silva, F. C. D. C., Santos, U. P., Oliveira, V. P., Castro, P. G., Melo Franco, L. T., \& Negri, F. (2012). Patterns of interaction between national and multinational corporations and Brazilian universities/public research institutes. Science \& Public Policy, 40(3), $281-292$.

Sjoerdsma, M., \& Van Weele, A. J. (2015). Managing supplier relationships in a new product development context. Journal of Purchasing and Supply Management, 21(3), 192-203. http://dx.doi.org/10.1016/j.pursup.2015.05.002.

Song, L. Z., \& Song, M. (2010). The role of information technologies in enhancing R\&D-marketing integration: an empirical investigation. Journal of Product Innovation Management, 27(3), 382-401. http://dx.doi.org/10.1111/j.1540-5885.2010.00723.x. 
Storbacka, K., Frow, P., Nenonen, S., \& Payne, A. (2012). Designing business models for value co-creation. Review of Marketing Research, 9, 51-78. http://dx.doi.org/10.1108/S1548-6435(2012)0000009007.

Tarute, A., \& Gatautis, R. (2014). ICT impact on SMEs performance. Procedia: Social and Behavioral Sciences, 110, 1218-1225. http:// dx.doi.org/10.1016/j.sbspro.2013.12.968.

Tavallaei, R., Hosseinalipour, M., \& Mohebifar, A. (2015). Top critical success factors for enterprises to benefit a prosperous learning through strategic alliances in developing countries. Procedia: Social and Behavioral Sciences, 194, 174-180. http://dx.doi.org/10.1016/j. sbspro.2015.06.131.

Tether, B. S. (2002). Who co-operates for innovation, and why. Research Policy, 31(6), 947-967. http://dx.doi.org/10.1016/S00487333(01)00172-X.

Tontini, G. (2016). Identifying opportunities for improvement in online shopping sites. Journal of Retailing and Consumer Services, 31, 228-238. http://dx.doi.org/10.1016/j.jretconser.2016.02.012.

Ulmanis, J., \& Deninšs, A. (2012). A management model of ICT adoption in Latvia. Procedia: Social and Behavioral Sciences, 41, 251264. http://dx.doi.org/10.1016/j.sbspro.2012.04.029.

Urraca-Ruiz, A., \& Amorim, R. B.. (2010). Diferenças de comportamento inovador entre empresas nacionais e estrangeiras no Brasil. Revista Brasileira de Inovação, 9(1), 29-68. http://dx.doi.org/10.20396/rbi.v9i1.8648993.

Van Echtelt, F. E. A., Wynstra, F., Van Weele, A. J., \& Duysters, G. (2006). Summary for policymakers. In Intergovernmental Panel on Climate Change. Climate change: the physical science basis (pp. 1-30). Cambridge: Cambridge University Press. http://doi.org/10.1017/ CB09781107415324.004.

Venkatesh, V., Davis, F. D., \& College, S. M. W. (2012). Theoretical acceptance extension model. Field Four Studies of the Technology Longitudinal, 46(2), 186-204.

Vilaseca-Requena, J., Torrent-Sellens, J., \& Jiménez-Zarco, A. 1. (2007). ICT use in marketing as innovation success factor: enhancing cooperation in new product development processes. European Journal of Innovation Management, 10(2), 268-288. http://dx.doi. org/10.1108/14601060710745297.

Wang, C., Fergusson, C., Perry, D., \& Antony, J. (2008). A conceptual case-based model for knowledge sharing among supply chain members. Business Process Management Journal, 14(2), 147-165. http://dx.doi.org/10.1108/14637150810864907.

Wang, C.-H. (2015). Using quality function deployment to conduct vendor assessment and supplier recommendation for businessintelligence systems. Computers \& Industrial Engineering, 84, 24-31. http://dx.doi.org/10.1016/j.cie.2014.10.005.

Wasti, N. S., \& Liker, J. K. (1997). Risky business or competitive power? Supplier involvement in japanese product design. Product Innovation Management, 14(5), 337-355. http://dx.doi.org/10.1016/S0737-6782(97)00024-6.

Watkins, A., Papaioannou, T., Mugwagwa, J., \& Kale, D. (2015). National innovation systems and the intermediary role of industry associations in building institutional capacities for innovation in developing countries: a critical review of the literature. Research Policy, 44(8), 1407-1418. http://dx.doi.org/10.1016/j.respol.2015.05.004.

Wong, C. W. Y., Wong, C. Y., \& Boon-ltt, S. (2013). The combined effects of internal and external supply chain integration on product innovation. International Journal of Production Economics, 146(2), 566-574. http://dx.doi.org/10.1016/j.jpe.2013.08.004.

$\mathrm{Wu}$, J., Wu, Z., \& Si, S. (2016). The influences of internet-based collaboration and intimate interactions in buyer: supplier relationship on product innovation. Journal of Business Research, 69(9), 3780-3787. http://dx.doi.org/10.1016/j.jbusres.2015.12.070.

Xu, L., Cui, N., Qualls, W., \& Zhang, L. (2017). How socialization tactics affect supplier-buyer co-development performance in exploratory and exploitative projects: the mediating effects of cooperation and collaboration. Journal of Business Research, 78, 242-251. http:// dx.doi.org/10.1016/j.jbusres.2016.12.019.

Zhou, N., Nagaligam, S., \& Lin, G. (2007). Application of virtual CIM in small and medium manufacturing enterprises. In Proceedings of the 35th International MATADOR Conference (pp. 161-164). London: Springer. http://dx.doi.org/10.1007/978-1-84628-988-0_35. 